\title{
折紙に対するランダムな 1 回の折りによって現れる多角形の出現比率の検証
}

三谷 純 Jun MITANI

概要:正方形の折紙を 1 回だけ折って開くと, 正方形を横 切る直線が 1 本現れる.この直線によって正方形は二つ の多角形に分割される. 直線が四隅の頂点を通る特殊な ケースを除くとこの二つの多角形は四角形と四角形，ま たは，三角形と五角形のどちらかの組み合わせとなる. 折 紙をランダムに 1 回折った場合に, それぞれの多角形の 組み合わせの出現する比率はいくつであるだろうか.この 問題を数学的解法で求め, 出現比率が 1 対 $\sqrt{2}$ であるとの 結果を得た. また, コンピュータを用いた数值解の算出に よって結果の妥当性を検証した.

キーワード:平面幾何学／折紙

\section{1. はじめに}

正方形の折紙を 1 回だけ折って開くと, 正方形を横切る 直線が 1 本現れる.この直線によって正方形は二つの多 角形に分割される. 直線が四隅の頂点を通る特殊なケー スを除くと,この二つの多角形は四角形と四角形, または, 三角形と五角形のどちらかの組み合わせとなる(以降で は, 簡単のためにそれぞれを(4,4)分割, および(3,5)分割 と記すこととする). 本稿では, 以下の問いに対する解を 求めることを目的とする.

問い:正方形の紙をランダムに 1 回折って開いた時, $(4,4)$ 分割と(3,5)分割の出現する比率はいくつである.

\section{2. ランダムな点の配置による多角形の出現比}

芳賀は文献[1][2][3]において前述の「問いと類似した 以下のような考察を紹介している.

平面上に折紙を配置し, 1 つの頂点を手前に折り返し た時に,どのような多角形が手前側に生じるか検証する.

図 1(文献[1]より引用) は, 右下頂点を様々に折り返した 様子を示し, a,b,c は三角形, d,e,f は四角形が生じている. 図 2(文献[1]より引用) は五角形が生じる例である. 芳賀 は, 図 3(文献[1]より引用)に示すように, ランダムに点を 配置し，その点に折紙の右下頂点が重なるように折ること で, 何角形ができるかを調べ, 結果として図 4(文献[1]より 引用. 領域に対応する多角形名の文字は本稿で加筆)に 示すような点の位置と生じる多角形の分布図を得ている. 折紙の 1 辺の長さを 1 としたときの, それぞれの領域の面 積は, 計算によって以下のように求められている.

$$
\begin{array}{ll}
\text { 三角形領域の面積 }=\frac{\pi}{2}-1 & (=0.5708) \\
\text { 四角形領域の面積 }=\pi \quad(=3.1416) \\
\text { 五角形領域の面積 }=\frac{\pi}{2}+3 \quad(=4.5708)
\end{array}
$$

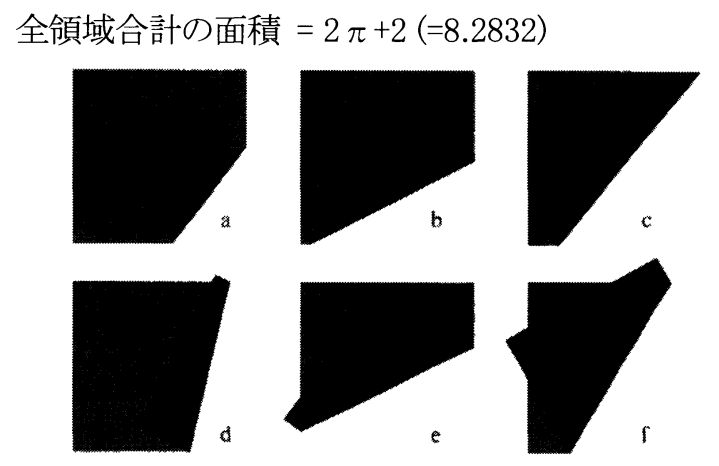

図1. 右下頂点を折り返した様子. a,b,cはは角形，d,e,f は四角形が生成される(文献[1]より引用).

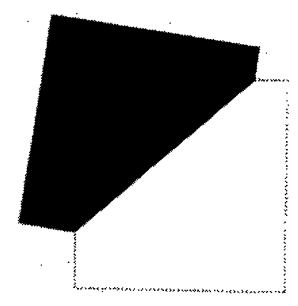

図 2. 右下頂点を折り返して五角形が生成されるケー ス(文献[1]より引用).

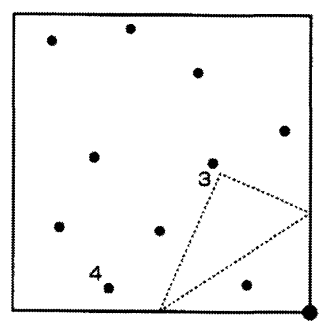

図 3. ランダムに点を描いて，その点に右下頂点を重 ねて折る(文献[1]より引用).

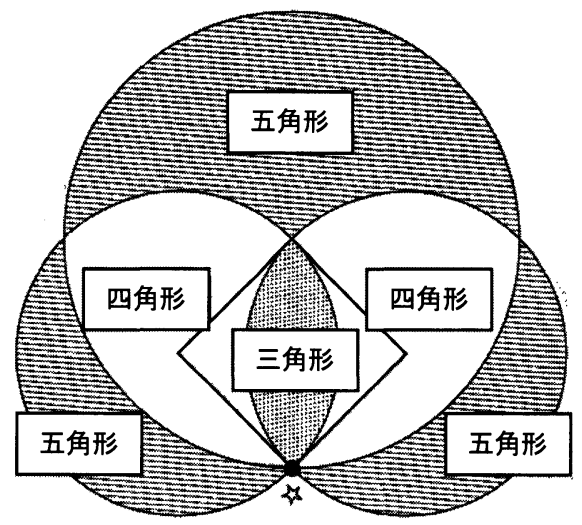

図 4. 頂点の移動先と多角形の種類別の分布図(文献 [1]より引用. 多角形名は後から加筆).

このような検証に問題はないが, 文献[1][2][3]では, こ こで得られた多角形の種類別の分布図の面積比が, 折紙 
をランダムに折った時(「任意に1回折ってもらったとき(文 献[1]より)」)に出現する多角形の比率と一致するであろう という前提で考証している点に問題がある. ランダムに折 紙を折った時に出現する多角形の比率と, 上記で述べた 分布図の面積の比率とは直接的な関係がないと考えられ るからである. 例えば, 図 2 に示す五角形が現れる折り方 の裏と表を反転させれば, 三角形になるわけであるから， 裏と表の区別をしなければ三角形と五角形の出現比率は 等しくなるべきだと考えられる. また, 図 5 に示すように, 三角形になるケースでは移動後の頂点が折り線に近く, 折り線が少し振れると頂点は少し動く. 一方で五角形にな るケースでは頂点が折り線から遠く, 折り線が少し振れた だけでも頂点の移動量は大きい.このような理由から，五 角形領域の面積が三角形領域の面積よりも大幅に大きく なっているのではないかと考えられる. 実験では約 3 分の 2 の被験者が三角形となったと記しており,この值は全領 域に占める三角形領域の面積率(6.89\%)と大きく異なる.

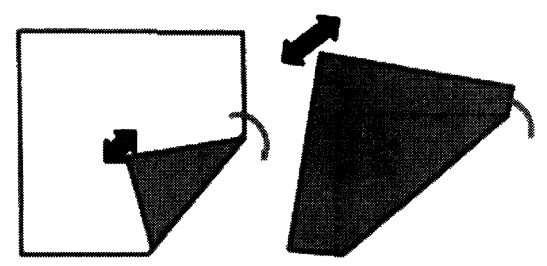

図 5 三角形になるケース(左)よりも五角形になるケー ス(右)の方が，折り線が振れた場合の頂点の移動量が 大きい.

\section{3. ベルトランのパラドックス}

そもそも, 幾何的な性質に関して確率の議論をすること は難しい. ベルトランのパラドックスと呼ばれる有名な問い がある.ここでは, Wikipedia[4]およびWebサイト[5]にて紹 介されているベルトランのパラドックスについて紹介する. この問題は以下のとおりである.

ベルトランのパラドックス問題(文献[5])

与えられた円に交わる直線を引くとき, その円に内接する 正三角形の1辺の長さよりも長くなる確率はいくらか.

この問は, 異なる考え方によって異なる解が得られる. 文 献[5]に記載されている解を以下に 2 通り紹介する.

（1）直線が円と交わった 2 点のうち片方を A とし，A を頂 点とする円の内接正三角形の残りの頂点を $\mathrm{B}, \mathrm{C}$ とする. このとき, 直線と円のもう一方の交点が円弧 $\mathrm{BC}$ の間にあ る時に内接正三角形の一辺より長くなる(図 6). 円弧 BC は円周の 3 分の 1 なので, 求める確率は $1 / 3$ である.

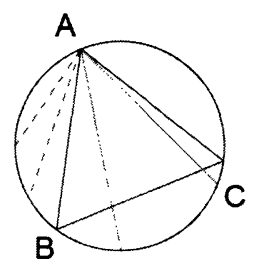

図 6 直線と円の交わり(1).
（2）円と交わる直線に垂直な半径を $\mathrm{AB}$ とする. 点 $\mathrm{A}$ を頂 点とする円の内接正三角形の点 $A$ の対辺と直径 $A B$ との 交点を $\mathrm{P}$ とする. また, 点 $\mathrm{B}$ を頂点とする円の内接正三角 形の点 $\mathrm{B}$ の対辺と直径 $\mathrm{AB}$ との交点を $\mathrm{Q}$ とする. 円と交わ る直線との交点を $X$ とすると, 点 X が線分 $P Q$ に含まれる 時に内接正三角形の一辺より長くなる(図 7). 線分 $\mathrm{PQ}$ の 長さは直径の半分なので, 求める確率は $1 / 2$ である.

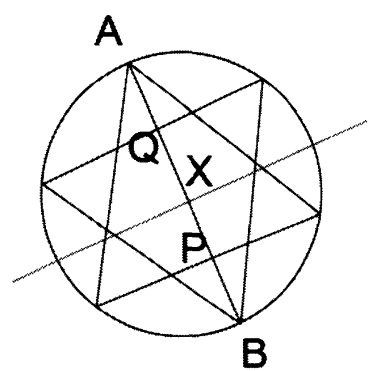

図 7 直線と円の交わり(2).

\section{4. ランダムな折り}

ベルトランのパラドックスは「ランダムに直線を引くとは どのようなことか」の定義によって解が異なるということを示 す例である. どちらが正しい, といらのではなく, ランダム な直線の定義が明確であれば，それに対する解は一意 に求まる. 本稿で対象とする問題も, 同じようにランダムな 折りを明確に定義する必要がある.

本稿で対象とする「ランダムに折る」のモデル化は Wikipedia[4]に記載されているような, 以下で考えることと する.

上空からストローを落下させた時に, ストロー（を延長した 直線)が折紙を横切る直線を折り筋として折りたたむ。

2 章で紹介した芳賀の方法では,「折紙の右下頂点とラ ンダムに配置した点の垂直二等分線を折り筋とする」とい う方法で折り線を決めたものと言い換えることができる.こ の方法は, 本稿で定義するランダムな折り方と異なるため, 結果も異なるものとなる.

\section{5. 数学的解法(1)}

\section{1 直線のパラメータ化}

折紙を図 8 に示寸正方形 $\mathrm{ABCD}$ とし, 折り線を直線 1 と する. 原点から 1 に降ろした垂線の足を $\mathrm{H}$ とするときに， $\mathrm{OH}$ の長さを $\mathrm{d}$, および $\mathrm{x}$ 軸と $\mathrm{OH}$ の成す角を $\theta$ とし，この 2 つを直線 1 を表現するパラメータに用いる. このような 2 つのパラメータを用いた直線の表現方法は, 画像から直 線を抽出するアルゴリズムとして一般的に用いられる Hough 変換でも用いられる方法である. 


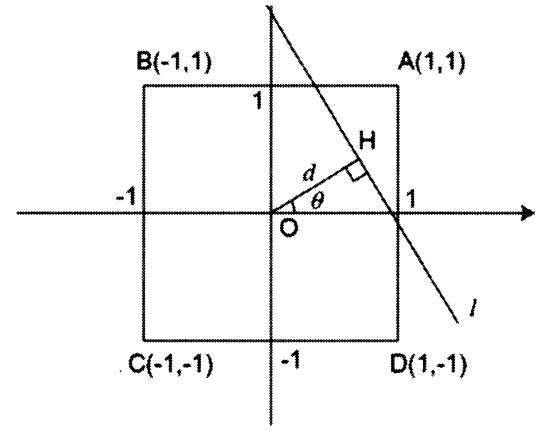

図 $8 d と \theta$ を用いた直線の表現.

\section{2. 解法}

直線 1 によって, 正方形がどのように分割されるかを考 える. 対称性より $\mathrm{d}>0,0<\theta \leqq \pi / 4$ の範囲のみ対象とする. $\theta$ を固定して考え, 1 が点 $\mathrm{D}$ を通る時の $\mathrm{d}$ の值を $\mathrm{d}_{\mathrm{D}}$, 点 $\mathrm{A}$ を通る時の值を $\mathrm{d}_{\mathrm{A}}$ とするとき, $\mathrm{d}$ の值と分割方法の関係は 次のようになる(図 9).

$0<\mathrm{d}<\mathrm{d}_{\mathrm{D}}:(4,4)$ 分割

$\mathrm{d}_{\mathrm{D}}<\mathrm{d}<\mathrm{d}_{\mathrm{A}}:(3,5)$ 分割

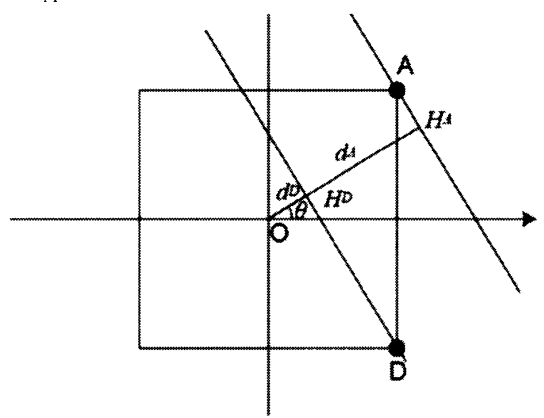

図 $9 \mathrm{~d}$ の值による直線 の位置.

$\mathrm{d}_{\mathrm{A}}, \mathrm{d}_{\mathrm{D}}$ の值は図 10 より, 次のようになる.

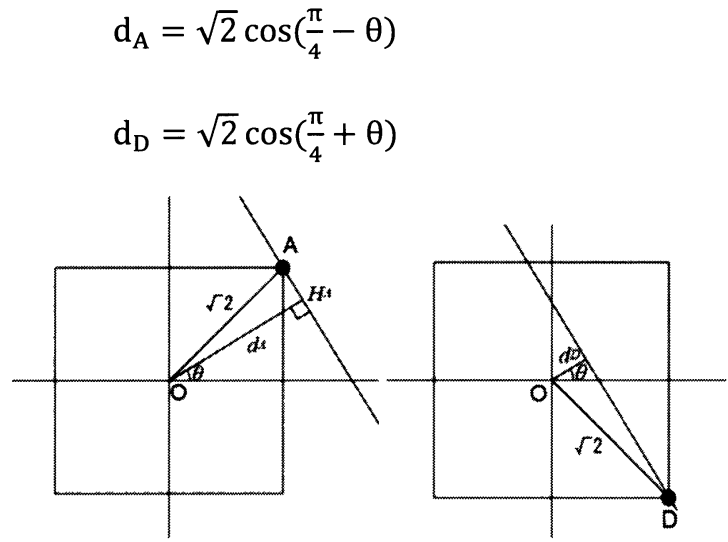

図 10 が点Aを通る場合(左)と点Dを通る場合(右)，

$\theta$ を横軸, $\mathrm{d}$ を縦軸と取ったとき,それぞれの值による分 割方法の関係は図 11 のようになる. 図中(A)が(3,5)分割, (B)が $(4,4)$ 分割の領域であり, (A)の上側の曲線は $\mathrm{d}=\sqrt{2} \cos \left(\frac{\pi}{4}-\theta\right)$, (B) との境界を成す曲線は $\mathrm{d}=\sqrt{2} \cos \left(\frac{\pi}{4}-\theta\right)$ である.

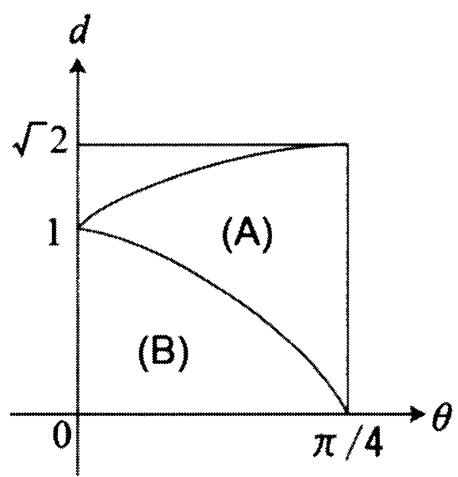

図 $11 \theta, \mathrm{d}$ の值之分割方法の関係.

(A),(B)それぞれの領域を積分で求めると次のようになる.
$(A)+(B)=\sqrt{2} \int_{0}^{\frac{\pi}{4}} \cos \left(\frac{\pi}{4}-\theta\right) d \theta=1$
(B) $=\sqrt{2} \int_{0}^{\frac{\pi}{4}} \cos \left(\frac{\pi}{4}+\theta\right) d \theta=\sqrt{2}-1$
(A) $=2-\sqrt{2}$

従って,

$(3,5)$ 分割 : $(4,4)$ 分割

$=$ (A)の面積:(B)の面積

$=\sqrt{2}: 1$

\section{6. 数学的解法(2)}

$\mathrm{x}$ 軸との成す角が $\theta$ の直線を平行に移動させることを 考える. 対称性加 $\pi / 4 \leqq \theta<\pi / 2$ のみ考慮すると, 図 12 に示寸ように, 水平な 2 辺と交わる領域(B)では $(4,4)$ 分 割となり, 互いに垂直な 2 辺と交わる領域(A)では $(3,5)$ 分 割となる. 正方形の 1 辺を 1 とすると, それぞれの領域の 幅は $\sin \theta-\cos \theta, \sin \theta$ となるので, これを $\theta$ について積 分すると, 次のような比を求めることができる.

$$
\begin{aligned}
& \text { (A): }(B)=2 \int_{\frac{\pi}{4}}^{\frac{\pi}{2}} \cos \theta d \theta: \int_{\frac{\pi}{4}}^{\frac{\pi}{2}}(\sin \theta-\cos \theta) d \theta \\
& =\sqrt{2}(\sqrt{2}-1): \sqrt{2}-1 \\
& =\sqrt{2}: 1
\end{aligned}
$$

従って,

$$
\begin{aligned}
& (3,5) \text { 分割: }(4,4) \text { 分割 } \\
& =\sqrt{2}: 1
\end{aligned}
$$

である.

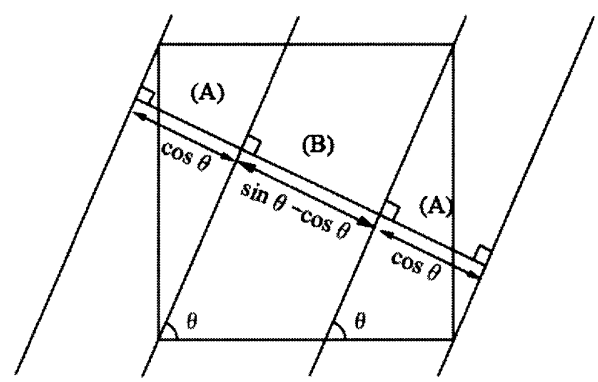

図 12 頂点の移動先と多角形の種類別の分布図. 


\section{7. 計算機による検証}

ランダムな要素を含む確率の問題に対しては, 計算機 によるシミュレーションがよく用いられる. そこで, 本稿でも 計算機を用いたシミュレーションで解を求めたので，その 結果を紹介する. まず, 一定の微小な間隔を置いて存在 する平行直線群 (無限長) と正方形の交わり方を調べる (図 13). 平行直線群は一定角度ずつ回転させることとす る.これで, 平面空間を満たすあらゆる直線を離散的に表 現するものとする. ところで, 直線群を回転させる代わりに 正方形の方を回転させても問題は変わらない(図 14).こ ちら方がプログラムの実装が容易なため, 正方形を回転 させて交わり方を調べる. 対称性より回転角は $0 \sim \pi / 4$ を 調べるものとする. 図 15 に示すプログラムを用いた.

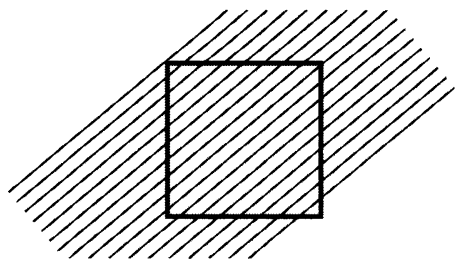

図 13 平行な直線群との交わり.

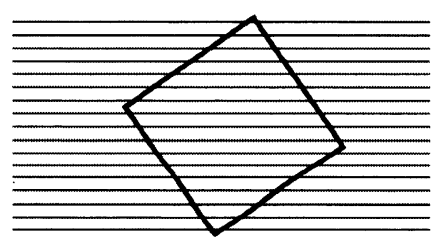

図 14 水平な直線群と, 回転させた正方形の交わり.

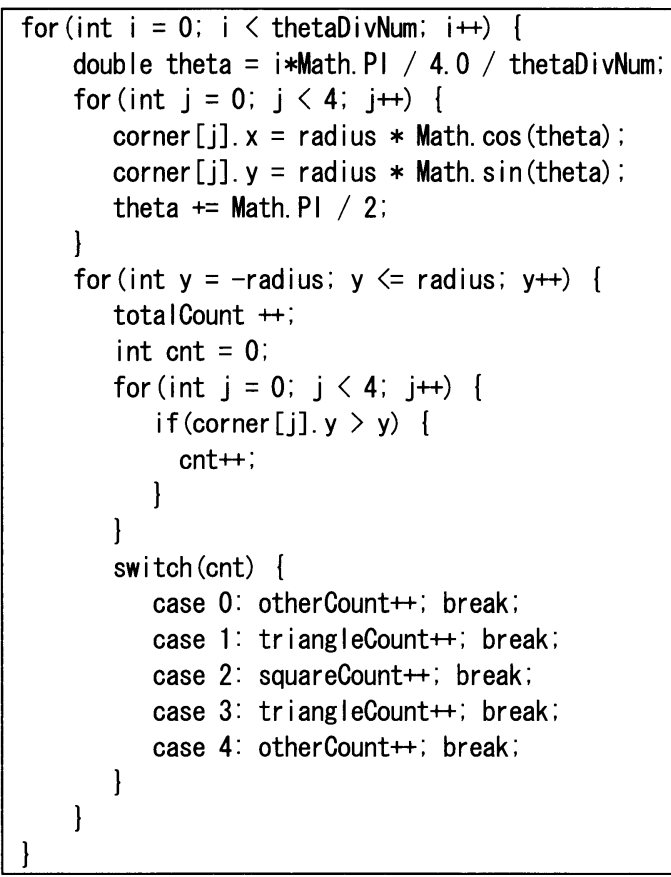

図 15 直線群と正方形の交わりをシミュレートするプロ グラムコード.

$\mathrm{x}$ 軸に水平な直線を $-1 \leqq \mathrm{y} \leqq 1$ の間に 2 万本配置し, 正
方形を 0〜45 度の間を 10000 分割した回転を行うことで， 約 2 億通りの分割実験を行った.

その結果は次のとおりであった。

(3,5)分割: 105488527

(4,4)分割: 74577604

交差せず:19943869

試行回数: 200010000

$(3,5)$ 分割 $/$ 交差した試行回数 $=0.5858321$

$(3,5)$ 分割/(4,4)分割 $=1.4144799690802616$

$(3,5)$ 分割 : $(4,4)$ 分割

$=1.4144 \cdots \cdots: 1$

$\fallingdotseq \sqrt{2}: 1$

\section{6. まとめ}

正方形の折紙をランダムに折った時に, その折り線に よって分割されて生成される多角形の出現比率を, 計算 および計算機を用いたシミュレーションで求めた. ランダ ムな折り方の定義によって, 求まる解はことなるが，本稿 で用いた定義では，三角形と五角形，四角形と四角形に

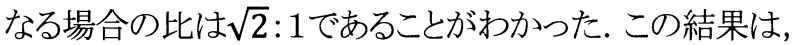
文献[1]で記されている「実験で約 3 分の 2 の被験者が三 角形となった」といら結果に対して, 図 4 に示寸分布図の 面積比を用いる方法よりもよい説明を与えるものと考えら れる.

\section{参考文献}

［1］芳賀和夫, “オリガミクスへの招待 第 1 回”, 季刊誌 「をる」No.9, p64-67, 1995.

［2］芳賀和夫, “数理を楽しむオリガミクス 6”, 折紙探 偵団 72 号, p.14-15, 2002.

［3］芳賀和夫, “オリガミクスによる数学授業”, 明治図書 出版, 1996

[4] Wikipedia, http://en.wikipedia.org/wiki/Bertrand\%27s_paradox_( probability)

［5］安田富久一, “数学的活動を大切にする”, http://www.nikonet.or.jp/spring/katudou/katudou.h tm

\section{著者紹介}

みたに じゅん：筑波大学システム情報工学研究科コ ンピュータサイエンス専攻 兼 科学技術振興機構さきが け, 305-8573, 茨城県つくば市天王台 1-1-1 